\title{
The Efficacy of Andrographolide and its Combination with Betulinic Acid in the Treatment of Triple Negative Breast Cancer
}

\author{
*Daniel Weber ${ }^{1,2,3}$, Mixia Zhang*, Pengwei Zhuang ${ }^{1}$, Yanjun Zhang ${ }^{1}$, Janelle Wheat ${ }^{2}$ and Geoffrey Currie ${ }^{2}$ \\ ${ }^{1}$ Tianjin University of Traditional Chinese Medicine, China \\ ${ }^{2}$ Department of Health Sciences, Charles Sturt University, Australia \\ ${ }^{3}$ National Institute for Integrative Medicine (NIIM), Australia
}

Submission: March 22, 2017; Published: March 31, 2017

"Correspondence Address: Daniel Weber, Charles Sturt University, 74 Brandling St Alexandria 2015 NSW Australia, Tel: +61 299592233 ;

Email: dweber@niim.com.au

Abstract

Purpose: Breast Cancer is the most prevalent form of cancer in women around the world. Breast cancers that do not express the genes for estrogen receptor, progesterone receptor and human epidermal growth factor receptor 2 (HER2) are referred to as triple-negative breast cancers (TNBC). TNBC has a relatively poorer prognosis than the major breast cancer sub-types with conventional chemotherapy eventually failing due to acquired drug resistance, toxic side effects and the presence of a deregulated immune response. Hence, there is an urgent need for new treatment approaches. New treatments for overcoming these drawbacks include the use of plant extracts.

Study design: In this study, we investigated the efficacy and the underlying molecular mechanism(s) of Andrographolide (Andro), a naturally abundant phytochemical against TNBC MDA-MB-231 and MDA-MB-468cell lines. The efficacy of the combination of Andro with Betulinic Acid (BetA) was also determined.

Results: Here we report that Andro was able to inhibit the inflammatory response, inhibit angiogenesis and cause cell cycle arrest ultimately causing apoptosis in TNBC cells. Our findings support that the identification of naturally occurring anti-tumour compounds may provide a chemotherapeutic approach for the treatment of TNBC.

Conclusion: Overall, our results provide a molecular basis for the ability of Andro and BetAto mediate apoptosis, suppress inflammation and inhibit angiogenesis in TNBC cell lines.

Keywords: TNBC; Drug Resistance; Toxicity; Phytochemical; Andrographolide; Betulinic Acid

\section{Introduction}

Breast cancer accounts for approximately 30 per cent of all female cancers andis the most common malignancy in women [1]. The causes of breast cancer are multi-factorial and the period of development can span decades and clinical course is highly variable.Triple-negative breast cancer (TNBC) (estrogen receptor negative, progesterone receptor and Her-2-negative) accounts for 10 to 20 per cent of all breast cancers [2]. TNBC are considered to be more aggressive than other types of breast cancer and have poorer prognosis [3]. The cause of death of patients with TNBC is often recurrence and metastasis (30-40\% of cases) [4]. Unfortunately, the anticancer efficacy of commonly used chemotherapeutic agents for TNBC, is limited due to the development of acquired drug resistance and toxicities [5]. Therefore the need for new therapeutics in the fight against cancer is clearly warranted.
Extensive evidence has lately emerged indicatingthat most chronic diseases, including cancer, are caused by a deregulated inflammatory response in addition to genetic alterations [6]. A deregulated inflammatory response is particularly evident in breast cancer [7]. The identification of transcription factors such as NF- $\kappa \mathrm{B}, \mathrm{AP}-1$ and STAT3 and their gene products tumour necrosis factor (TNF), interleukin-1 (IL-1) and interleukin-6 (IL6) has provided the molecular basis for the role of inflammation in cancer. The activation of these inflammatory pathways has been associated in the transformation, survival, proliferation, invasion, angiogenesis, metastasis and resistanceof cancer cells [8].

Herbal medicines and their extracts have been shown to impact cytokines and inflammatory markers offering a great 


\section{Cancer Therapy \& Oncology International Journal}

potential in the fight against cancer. Herbal extracts including andrographolide (Andro) and betulinic acid (BetA) inhibit the process of carcinogenesis, induce cell cycle arrest, and inhibit signal transduction pathways. Andro, a labdanediterpenoid, is the main bioactive component of the medicinal plant Andrographispaniculata. Androis traditionally used as a medicine to treat many diseases in India, China and Southeast Asia such as common cold, myocardial ischemia, pharyngotonsillitis and respiratorytractinfections [9]. It has also been reported to have anti-cancer, anti-inflammatory and anti-allergic activities $[10,11]$. BetA, a pentacyclictriterpene discovered in 1995 from the stem bark of the plant Zizyphusmauritiana, was initially reported to be a melanoma-specific cytotoxic agent [12]. Since then, BetA was found to exhibit a variety of biological and medicinal properties such as anti-bacterial, anti-malarial, antiinflammatory and anti-cancer activities in addition to the ability to inhibit the human immunodeficiency virus (HIV) [13].

We previously reported on the cytotoxic, anti-inflammatory and anti-angiogeniceffects of BetA in TNBC cell lines. In the present study, we investigated the cytotoxic effect of Andro on MDA-MB-231 and MDA-MB-468 breast carcinoma cell lines cells. Furthermore, the anti-inflammatory and anti-angiogenic potential of Andro and its combination with BetA were also examined. We hypothesized that Andro and its combination with BetA could induce apoptosis through cell cycle arrest and inhibit the pro-inflammatory response present in the breast carcinoma cell lines and possibly inhibit angiogenesis in human mammary microvascular endothelial cells (HMMEC). The findings of this study suggest that the use of Andro and its combination with BetA may serve as therapeutic approaches targeting inflammatory factors and cell cycle genes to help prevent the progression and metastasis of breast carcinoma cells (Figure 1).
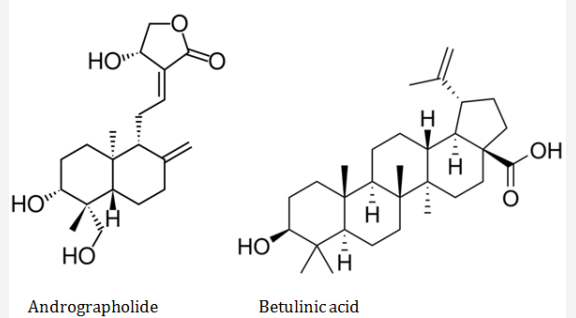

Figure 1: Structures of Andrographolide (Andro) and Betulinic Acid (BetA).

\section{Materials and Methods}

\section{Materials}

Andro andBetAwere obtained from Tianjin Zhongxin Pharmaceutical Group Corporation Limited (China. Purity>98\%). Human breast carcinoma cell lines MDA-MB-231 and MDAMB-468 [14] were obtainedfrom Foleibao Biological Technology Development Co.Ltd. (China). Human mammary microvascular endothelial cells (HMMEC), endothelial cell medium (ECM), fetal bovine serum (FBS), endothelial cell growth supplement (ECGS), penicillin/streptomycin (PS), for cell culture were purchased from ScienCell research laboratories (USA). Dulbecco's PhosphateBuffered Saline (DPBS)and L15, F-15 and RPMI 1640 media for cell culture were purchased from Hyclone (USA).0.25\% Trypsin and $0.02 \%$ EDTAwere purchased fromGibco (China), Matrigel was obtained from BD Biosciences (USA) whereas DMSO and 3-(4,5-Dimethylthiazol-2-yl)-2,5-diphenyltetrazolium bromide for MTT assay were purchased from Solarbio (China). RNA was extracted using TRIzol reagent and TRIzol plus RNA purification kit purchased from Tiangen (China). 1\% agarose gel and RT-PCR kit were obtained from Takara Bio Inc.(China). Fibronectin (FN) was obtained fromSigma (USA).

\section{Cell culture and drug preparation}

Human breast carcinoma cell lines MDA-MB-231 and MDAMB-468 and HMMEC were recovered and cultured according to previously described methods [15]. Andro and BetA were first dissolved in Dimethyl sulfoxide (DMSO) then diluted to the required concentrations with milli- $Q(\mathrm{mQ})$ water and filtered to sterilize. DMSO was used to enhance the solubility of the extracts with a final concentration of $3 \%$.

\section{Drug cytotoxicity}

MDA-MB-231, MDA-MB-468, and HMMEC cells were seeded at a density of $5 \times 104$ cells $/ \mathrm{mL}$ in flat-bottomed 96 -well culture plate in FBS-free F-15 culture medium and incubated for $24 \mathrm{~h}$ at $37^{\circ} \mathrm{C}$ in a humidified atmosphere to allow the cells to attach. Treatments with Andro ranged between concentrations of $0.625 \mu \mathrm{g} / \mathrm{mL}$ and $160 \mu \mathrm{g} / \mathrm{mL}$ depending on the cell type with six wells per concentration. The plate was left to incubate under normal growth conditions for $24 \mathrm{~h}$. Images of the cells and observations on the morphological changes after drug treatments were conducted using an inverted phase contrast microscope (DC300F, Leica). The inhibition of cell growth and IC50 values was determined using the 3-(4,5-Dimethylthiazol-2yl)-2,5-diphenyltetrazolium bromide (MTT) assay according to previously described methods [15].

\section{The mRNA expression of inflammatory factors and cell-cycle related genes}

RT-PCR was used to determine the expression of inflammatory and cell-cycle related genes in human breast carcinoma cell lines MDA-MB-231 and MDA-MB-468 following treatment with Andro and its combination with BetA. The mRNA expression levels of vascular endothelial growth factor (VEGF) and basic fibroblast growth factor (bFGF) in HMMEC were also determined using RT-PCR to identify their association with tubelike structure formation. The cells were treated in triplicate with Andro at concentrations of $1 \mu \mathrm{g} / \mathrm{mL}, 10 \mu \mathrm{g} / \mathrm{mL}$ and $20 \mu \mathrm{g} / \mathrm{mL}$. After $24 \mathrm{~h}$ incubation, the cellular RNA was isolated using TRIzol reagent and TRIzol plus RNA purification kit (Tiangen, China). RNA concentration was determined by the measurement of OD with the nucleic acid protein analyzer at 260 nmon nucleic acid spectrometer (Beckman, Du530) and $\mathrm{OD}_{260} / \mathrm{OD}_{280}>1.8$ ensured 


\section{Cancer Therapy \& Oncology International Journal}

high quality RNA. The degree of RNA degradation was analyzed by electrophoresis. RNA $(4.5 \mu \mathrm{L})$ was mixed with $0.5 \mu \mathrm{L}$ sample buffer and the sample was electrophoresed on 1\% Agarose gel. The degree of RNA degradation was determined using Bio Imaging System (SYNGENE). Then the mRNA expressions of inflammatory factors TNF- $\alpha$, TLR4, NF- $\kappa$ B1, IL-6, STAT3, HIF1A and i-NOS, and cell cycle related genes Cipl/P21, Kipl/p27, CDK2, CDK6, and cyclin Dl with $\beta$-actin used as an internal control were determined using RT-PCR using a previously described method [15]. The level of mRNA expression was analyzed using the $2-\Delta \Delta$ CTmethod $[15,16]$. In this study, increased mRNA expression was defined as fold $\geq 2.0$, normal expression was afold ranging from 0.51 to 1.99 , and decreased mRNA expression was fold $\leq 0.5$ (Tables $1 \& 2$ ).

Table 1: Sequence of RT-PCR primers of inflammatory genes.

\begin{tabular}{|c|c|c|}
\hline Prime & Sequence & Product \\
\hline$\beta$-actin & $\begin{array}{c}\text { Forwardprimer: } \\
\text { AGAGCTACGAGCTGCCTGAC } \\
\text { Reverseprimer: } \\
\text { AGCACTGTGTTGGCGTACAG }\end{array}$ & $184 \mathrm{bp}$ \\
\hline TNF- $\alpha$ & $\begin{array}{c}\text { Forward primer: } \\
\text { CCTGTGAGGAGGACGAACAT } \\
\text { Reverse primer: } \\
\text { AGGCCCCAGTTTGAATTCTT }\end{array}$ & 240bp \\
\hline TLR4 & $\begin{array}{c}\text { Forward primer: } \\
\text { CCATAAAAGCCGAAAGGTGA } \\
\text { Reverse primer: } \\
\text { CTGAGCAGGGTCTTCTCCAC }\end{array}$ & $159 \mathrm{bp}$ \\
\hline NF-кB1 & $\begin{array}{c}\text { Forward primer: } \\
\text { TCGTTTCCGTTATGTATGT } \\
\text { Reverse primer: } \\
\text { CCTTGGGTCCAGCAGTTA }\end{array}$ & 227bp \\
\hline IL-6 & $\begin{array}{c}\text { Forward primer: } \\
\text { AGGAGACTTGCCTGGTGAAA } \\
\text { Reverse primer: } \\
\text { CAGGGGTGGTTATTGCATCT }\end{array}$ & $180 \mathrm{bp}$ \\
\hline STAT3 & $\begin{array}{c}\text { Forward primer: } \\
\text { TGTGCGTATGGGAACACCTA } \\
\text { Reverse primer: } \\
\text { AGAAGGTCGTCTCCCCTTA }\end{array}$ & $170 \mathrm{bp}$ \\
\hline HIF1A & $\begin{array}{c}\text { Forward primer: } \\
\text { GAAAACTTGGCAACCTTGGA } \\
\text { Reverse primer: } \\
\text { ATCTCCGTCCCTCAACCTCT }\end{array}$ & $194 b p$ \\
\hline
\end{tabular}

\begin{tabular}{|c|c|c|}
\hline \multirow{3}{*}{ i-NOS } & Forward primer: & \\
& CTCTATGTTTGCGGGGATGT & \\
& Reverse primer: & $179 \mathrm{bp}$ \\
& TTCTTCGCCTCGTAAGGAAA & \\
\hline
\end{tabular}

Table 2: Sequence of RT-PCR primers of cell-cycle related genes.

\begin{tabular}{|c|c|c|}
\hline Prime & Sequence & product \\
\hline$\beta$-actin & $\begin{array}{c}\text { Forward primer: } \\
\text { AGAGCTACGAGCTGCCTGAC } \\
\text { Reverse primer: } \\
\text { AGCACTGTGTTGGCGTACAG }\end{array}$ & $184 \mathrm{bp}$ \\
\hline p21 & $\begin{array}{c}\text { Forward primer: } \\
\text { TTAGCAGCGGAACAAGGAGT } \\
\text { Reverse primer: } \\
\text { GCCGAGAGAAAACAGTCCAG }\end{array}$ & $225 b p$ \\
\hline P27 & $\begin{array}{c}\text { Forward primer: } \\
\text { CGCTTTGTTTTGTTCGGTTT } \\
\text { Reverse primer: } \\
\text { TCTCTGCAGTGCTTCTCCAA }\end{array}$ & $221 b p$ \\
\hline CDK2 & $\begin{array}{c}\text { Forward primer: } \\
\text { GCCCTAATCTCACCCTCTCC } \\
\text { Reverse primer: } \\
\text { AAGGGTGGTGGAGGCTAACT }\end{array}$ & $211 b p$ \\
\hline CDK6 & $\begin{array}{c}\text { Forward primer: } \\
\text { AGCCCAAGATGACCAACATC } \\
\text { Reverse primer: } \\
\text { AGGTCAAGTTGGGAGTGGTG }\end{array}$ & $181 \mathrm{bp}$ \\
\hline Cyclin Dl & $\begin{array}{c}\text { Forward primer: } \\
\text { GAGGAAGAGGAGGAGGAGGA } \\
\text { Reverse primer: } \\
\text { AGAGATGGAAGGGGGAAAGA }\end{array}$ & $231 \mathrm{bp}$ \\
\hline
\end{tabular}

\section{Cell cycle kinetics}

MDA-MB-231 and MDA-MB-468 breast carcinoma cell lines were seeded at a density of $1 \times 104$ cells/well in flat-bottomed 12 well culture plate in the FBS-free L-15 culture medium. Cells were treated with Andro and its combination with BetA in triplicates. Following $48 \mathrm{~h}$ incubation, the cells were processed according to the previously described method [15]. The progression of cells through the cell cycle was examined by propidium iodide staining $(100 \mu \mathrm{g} / \mathrm{mL})$ with $1 \times 104$ events/treatment analysed using flow cytometry.

\section{Tube formation assay}

HMMEC, breast carcinoma cell lines and stromal cells were re-suspended in ECM made from 5\% FBS, 1\% P/S and 1\% ECGS, 


\section{Cancer Therapy \& Oncology International Journal}

and transferred into the coated flasks at $7.5 \times 103$ cells $/ \mathrm{cm} 2$. The morphology and number of tube-like formations of HMMEC were assessed using an inverted phase contrast microscope (DC300F, Leica) coupled to a digital camera. Three groups were set based on the cells tested; HMMEC alone, HMMEC in cocultivation with breast carcinoma cell lines and HMMEC in cocultivation with stromal cells. The cells were cultured according to previously described method [15]. Andro and its combination with BetA at concentrations of $1 \mu \mathrm{g} / \mathrm{mL}$ were added to triplicate wells. Preliminary experiments using concentrations of 1, 5 and $10 \mu \mathrm{g} / \mathrm{mL}$ showed that 5 and $10 \mu \mathrm{g} / \mathrm{mL}$ induced great cell death (results not shown). The number of tube-like structures formed was observed after 6,12, 24 and 36h.

\section{Statistical Analysis}

Each experiment was repeated at least three times and presented as mean \pm s.d. Statistical comparisons were carried out by ANOVA using SPSS13.0 software. $\mathrm{P}<0.05$ was considered statistically significant.

\section{Results}

\section{The effect of Andro on the morphology of MDA-MB-231 and MDA-MB-468 TNBC cell lines}

To determine the anti-proliferative activity of Andro, structure shown in figure 1, MDA-MB-231 and MDA-MB-468 breast carcinoma cell lines and HMMEC were treated with increasing concentrations of Andro for 24h. Microscopic examination of the three cell lines using an inverted phase contrast microscope revealed that the HMMEC was more sensitive to lower concentrations of Andro compared to the two TNBC cell lines with MDA-MB-468 showing the least sensitivity. MDA-MB-231 appeared to be more susceptible to Andro treatment with cell kill occurring at much lower concentrations compared to MDAMB-468 cell lines. At higher concentrations, Andro caused marked degree of cell kill and produced significant reduction in cell numbersin addition to significant morphological changes. Compared to the control, cells treated with these concentrations appeared to lose their characteristic spindle shape and necrotic cells, with cell debris also observed (Figure 2).

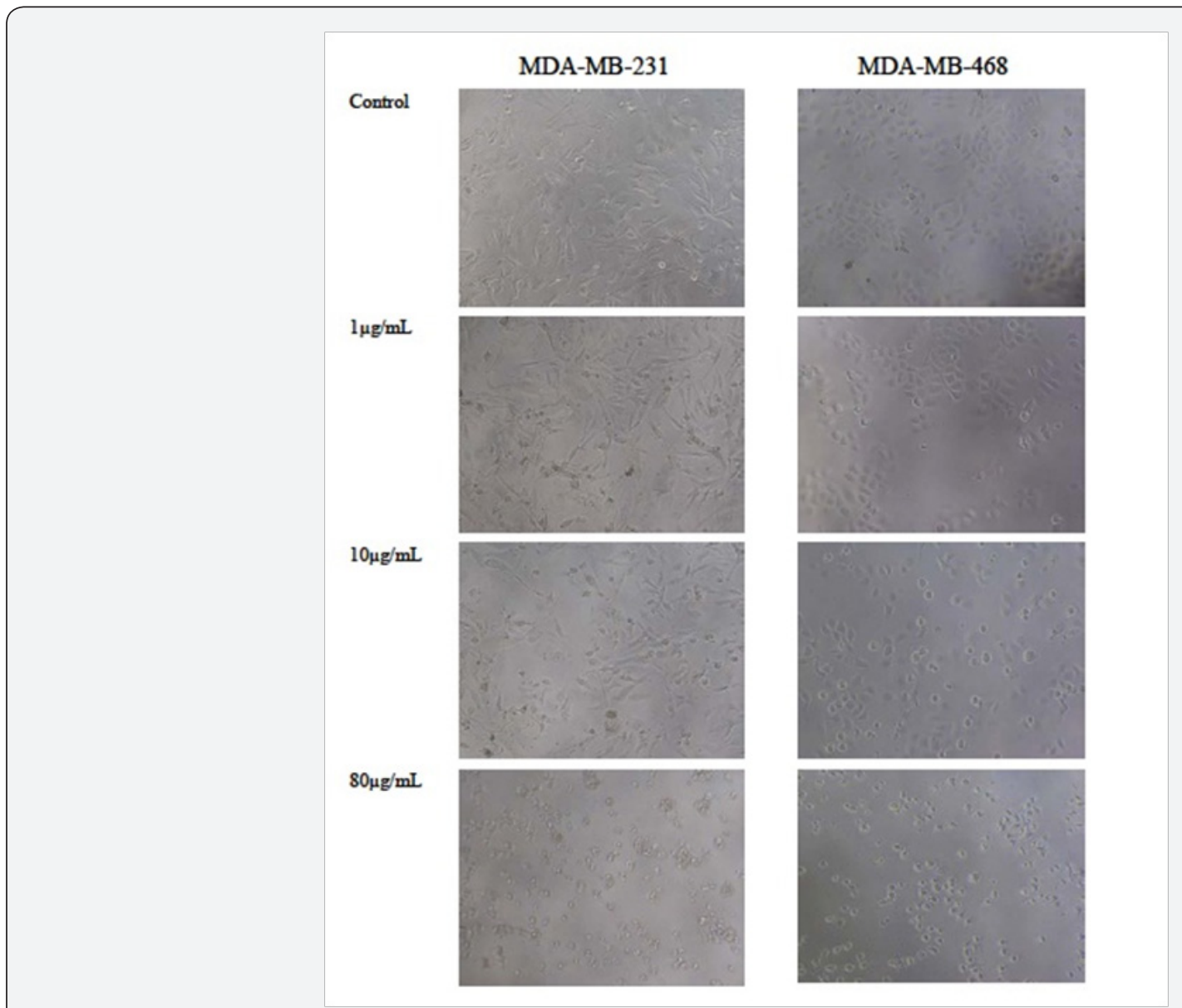

Figure 2: The effect of increasing concentrations of Andro on the cellular morphology of breast carcinoma cell lines MDA-MB-231 and MDAMB-468. Images were taken using an inverted phase contrast microscope set at $\times 40$ magnification.

\section{The cytotoxicity of Andro}

The cytotoxic effect of increasing concentrations of Androin HMMEC and the two breast carcinoma cell linesMDA-MB-231 and MDA-MB-468 is shown in Figure 3. Table 3 gives the IC50 values of Andro against the three cell lines i.e. the concentration of Andro required to kill 50\% of the cells. HMMEC, found earlier 


\section{Cancer Therapy \& Oncology International Journal}

to be more sensitive to Andro, had a much lower IC50 (7.1 $\mu \mathrm{g} /$ $\mathrm{mL}$ ) compared to MDA-MB-231 and MDA-MB-468 cell lines. The value of $39.6 \mu \mathrm{g} / \mathrm{mL}$ compared to an IC50 of $77.6 \mu \mathrm{g} / \mathrm{mLin}$ MDAactivity of Andro was greater against MDA-MB-231 with an IC50

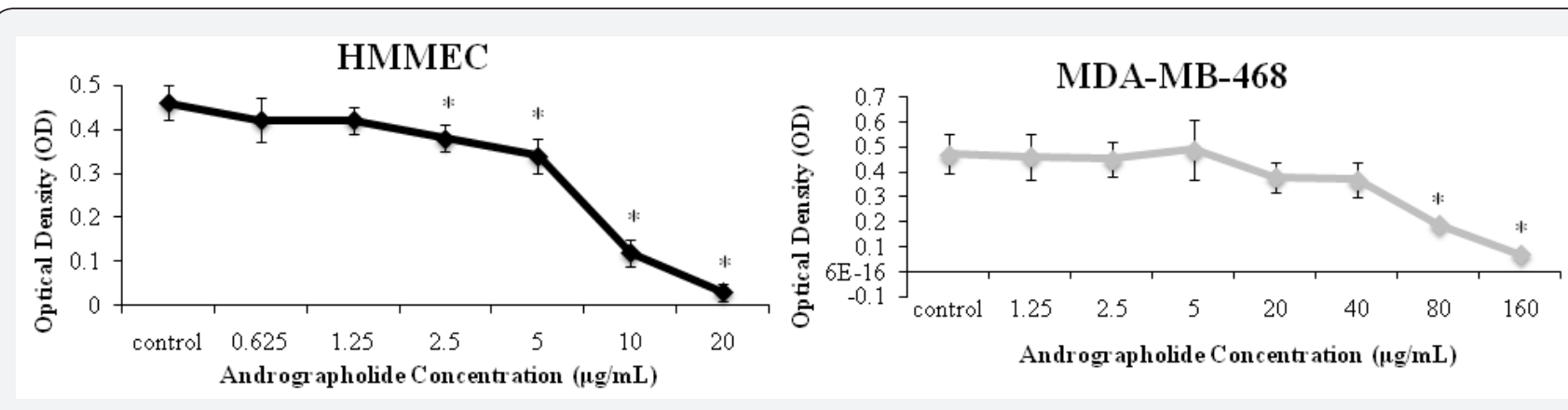

Figure 3: The effect of Andro on the proliferation of HMMEC, MDA-MB-231 and MDA-MB-468 cell lines. Cell proliferation was determined after 24h, using the MTT assay. Each point represents the mean of 6 independent experiments with vertical bars representing the standard deviation. * $p<0.05$ for comparison of optical density for that given concentration compared to the untreated control indicate statistical significance.

Table 3: IC50 values $(\mu \mathrm{g} / \mathrm{mL})$ of Andro against HMMEC and MDAMB-231 and MDA-MB-468 breast carcinoma cell lines.

\begin{tabular}{|c|c|}
\hline Cell line & Andro IC50 \\
\hline HMMEC & 7.1 \\
\hline MDA-MB-231 & 39.6 \\
\hline MDA-MB-468 & 77.6 \\
\hline
\end{tabular}

The effect of Androand its combination with BetAon the mRNA expression of inflammatory factors in TNBC cell lines

The involvement of inflammatory factors in cancer and the anti-inflammatory properties of the investigation of the inflammatory response to Andro in the breast carcinoma cell lines. The effect of 1, 10 and $20 \mu \mathrm{g} / \mathrm{mL}$ Andro on the mRNA expression of TNF- $\alpha$, TLR4, NF- $\kappa$ B1, HIF1A, IL-6, STAT3 and i-NOS was determined in MDA-MB-231 and MDA-MB-468 breast carcinoma cell lines cultured alone or co-cultured with breast stromal

Table 4: The effect of Andro on mRNA expression levels of inflammatory factors in breast cancer cell lines MDA-MB-231 and MDA-MB-468 and their co-culture with breast stromal cells*.

\begin{tabular}{|c|c|c|c|c|c|c|c|c|}
\hline Cell line & $\begin{array}{c}\text { Andro } \\
\text { Concentration }\end{array}$ & TNF- $\alpha$ & TLR4 & NF-kB1 & HIF1A & IL-6 & STAT3 & i-NOS \\
\hline $\begin{array}{c}\text { MDA- } \\
\text { MB-231 }\end{array}$ & $1 \mu \mathrm{g} / \mathrm{mL}$ & 1.50 & 0.72 & 0.75 & 0.65 & 3.86 & 0.47 & 0.45 \\
\hline & $10 \mu \mathrm{g} / \mathrm{mL}$ & 0.40 & 0.25 & 0.96 & 0.83 & 0.05 & 1.15 & 0.74 \\
\hline & $20 \mu \mathrm{g} / \mathrm{mL}$ & 5.01 & 0.03 & 0.60 & 0.42 & 0.00 & 0.30 & 0.24 \\
\hline & $5 \mu \mathrm{g} / \mathrm{mL} \dagger$ & 0.63 & 0.13 & 0.35 & 0.48 & 0.11 & 0.85 & 0.95 \\
\hline $\begin{array}{c}\text { MDA- } \\
\text { MB-468 }\end{array}$ & $5 \mu \mathrm{g} / \mathrm{mL}$ & 0.29 & 1.46 & 0.36 & 0.40 & 0.73 & 1.08 & 1.46 \\
\hline & $10 \mu \mathrm{g} / \mathrm{mL}$ & 0.33 & 1.34 & 0.42 & 0.34 & 0.74 & 0.57 & 0.90 \\
\hline & $20 \mu \mathrm{g} / \mathrm{mL}$ & 0.53 & 2.03 & 1.57 & 2.17 & 1.19 & 2.05 & 1.53 \\
\hline & $5 \mu \mathrm{g} / \mathrm{mL} \dagger$ & 0.16 & 1.12 & 1.47 & 1.05 & 2.13 & 1.52 & 0.77 \\
\hline & $10 \mu \mathrm{g} / \mathrm{mL} \dagger$ & 0.08 & 0.93 & 0.71 & 0.90 & 1.07 & 2.62 & 1.18 \\
\hline
\end{tabular}

The values represent fold change in expression of the target gene relative to the internal control gene ( $\beta$-actin) and untreated control cells. $\dagger$ Breast carcinoma cell lineco-cultured with breast stromal cells. cells. The treatment of MDA-MB-231 cells with $20 \mu \mathrm{g} / \mathrm{mL}$ Andro enhanced the expression of TNF- $\alpha$ andlowered the expression of all inflammatory factors except for the expression of NF-kB1. The expression levels of TNF- $\alpha$, STAT3 and i-NOS remained normal following treatment of MDA-MB-231 co-cultured with breast stromal cells with $5 \mu \mathrm{g} / \mathrm{mL}$ Andro, whereas the expression levels of TLR4, NF- $\kappa B 1$, HIF1A and IL- 6 were lowered. Although changes in the expression levels of the inflammatory factors of MDAMB-468 cell line generally remained normal, TNF- $\alpha, N F-\kappa B 1$ and HIF1Awere lowered following treatment with 5 and $10 \mu \mathrm{g} / \mathrm{mL}$ Andro. Similarly, Andro treatment ofMDA-MB-468 co-cultured with breast stromal cells lowered the expression of TNF- $\alpha$ only. The results indicate that Andro was more effective in blocking inflammation in MDA-MB-231 cell line by down regulating the expression of inflammatory factors. The combination of Andro and BetA lowered the expression of TLR4, NF- $\mathrm{kB} 1$ and IL-6in MDA-MB-231 whereas only TNF- $\alpha$ was lowered in MDA-MB-468 cell line (Tables 4 \& 5). 


\section{Cancer Therapy \& Oncology International Journal}

Table 5: The effect of combining Andro and BetA on the mRNA expression levels of inflammatory factors in MDA-MB-231 and MDA-MB-468cocultured with breast stromal cells*.

\begin{tabular}{|l|l|l|l|l|l|l|l|l|}
\hline Cells & $\begin{array}{l}\text { Andro+BetA } \\
\text { Concentration }\end{array}$ & TNF- $\alpha$ & TLR4 & NF-kB1 & HIF1A & IL-6 & STAT3 & i-NOS \\
\hline MDA-MB-231 & $5+5 \mu \mathrm{g} / \mathrm{mL}$ & 0.54 & 0.15 & 0.26 & 0.78 & 0.09 & 1.05 & 0.56 \\
\hline MDA-MB-468 & $5+5 \mu \mathrm{g} / \mathrm{mL}$ & 0.14 & 0.98 & 0.95 & 1.20 & 1.20 & 1.35 & 1.72 \\
\hline & $10+10 \mu \mathrm{g} / \mathrm{mL}$ & 0.24 & 1.22 & 1.03 & 0.85 & 1.52 & 4.67 & 3.09 \\
\hline
\end{tabular}

*The values represent fold change in expression of the target gene relative to the internal control gene ( $\beta$-actin) and untreated control cells.

\section{The effect of Androand its combination with BetAon} the cell cycle in TNBC cell lines

To examine the possible molecular mechanisms by which Andro and its combination with BetA induce cell cycle arrest in MDA-MB-231 and MDA-MB-468 breast carcinoma cell lines, treated cells were analysed for their DNA content by propidium iodide staining followed by flow cytometric analysis. Flow cytometric analysis of MDA-MB-231 cells co-cultured with stromal cells detected an increase in G1 DNA content in comparison with the control group whereas the percentage of cells in the $\mathrm{S}$ phase decreased following Andro treatment. The results suggest that Andro treatment of MDA-MB-231 cell line could lead to the inhibition of DNA synthesis causing the arrest of cells in the G1 phase, restraining the proliferation of cells. However, the treatment of MDA-MB-468 cell line with low concentrations of Andro, a slight increase in the percentage of cells in the $S$ phase was observed. To elucidate the exact mechanism by which Andro causes cell cycle arrest in MDAMB-468 cell line, further experiments with higher concentrations of Andro may to be conducted (Table 6).

Table 6: The effect of Andro on the cell cycle of breast carcinoma cell lines MDA-MB-231 and MDA-MB-468co-cultured with breast stromal cells.

\begin{tabular}{|c|c|c|c|c|}
\hline & Andro Concentration & $\mathbf{\% G}_{\mathbf{1}}$ & $\mathbf{\% G}_{\mathbf{2}}$ & $\mathbf{\%} \mathbf{S}$ \\
\hline & Control & $37.20 \pm 3.54$ & $11.15 \pm 0.50$ & $51.70 \pm 4.10$ \\
\hline MDA-MB-231 & $5 \mu \mathrm{g} / \mathrm{ml}$ & $45.50 \pm 5.94$ & $10.28 \pm 0.88$ & $44.25 \pm 6.86$ \\
\hline MDA-MB-468 & Control & $70.27 \pm 4.31$ & $23.39 \pm 1.32$ & $8.76 \pm 0.42$ \\
\hline & $5 \mu \mathrm{g} / \mathrm{ml}$ & $66.10 \pm 0.62$ & $21.65 \pm 0.91$ & $12.85 \pm 1.12$ \\
\hline & $10 \mu \mathrm{g} / \mathrm{ml}$ & $66.45 \pm 0.13$ & $20.82 \pm 2.84$ & $11.25 \pm 0.59$ \\
\hline
\end{tabular}

Table 7: The effect of combiningAndro and BetAon the cell cycle of breast carcinoma cell lines MDA-MB-231 and MDA-MB-468 co-cultured with breast stromal cells.

\begin{tabular}{|c|c|c|c|c|}
\hline & $\begin{array}{c}\text { Andro + BetA } \\
\text { Concentration }\end{array}$ & \%G1 & \%G2 & \%S \\
\hline MDA-MB-231 & Control & $37.20 \pm 3.54$ & $11.15 \pm 0.50$ & $24.95 \pm 7.00^{*}$ \\
\hline & $5+5 \mu \mathrm{g} / \mathrm{mL}$ & $40.75 \pm 5.16$ & $28.55 \pm 4.03$ & $8.76 \pm 0.42$ \\
\hline MDA-MB-468 & Control & $70.27 \pm 4.31$ & $23.39 \pm 1.32$ & $11.32 \pm 2.26$ \\
\hline & $5+5 \mu \mathrm{g} / \mathrm{mL}$ & $64.34 \pm 0.10$ & $21.25 \pm 2.02$ & $8.80 \pm 0.62$ \\
\hline
\end{tabular}

The combination of Andro and BetAwas found to significantly reduce the percentage of cells in the $S$ phase in MDA-MB-231 cell line (Table 7). The treatment of MDA-MB-231 cell line with BetA was previously reported to cause cell cycle arrest in the G2 phase [15]. The combination of the two drugs is found to increase the percentage of cells in G1 and G2 with greater percentage of cells in G2 phase suggesting that BetA, having higher activity, may be the driver of the G2 arrest rather than Andro at the concentrations tested. Unlike the slight increase in the percentage of cells in the $S$ phase following treatment of MDA-MB-468 cells with Andro, the combination Andro and BetA at $10 \mu \mathrm{g} / \mathrm{mL}$ lead to the restoration of the percentage of cells in the $\mathrm{S}$ phase to levels relative to the control.
The effect of Andro and its combination with BetA on the mRNA expression levels of cell-cycle related genes in TNBC cell lines

To further determine the effect of Andro on the cell cycle progression, the mRNA expression patterns of cell cycle genes of MDA-MB-231 and MDA-MB-468 TNBC cells were examined (Tables 8 \& 9) (Figure 4). In MDA-MB-231 cell line, Andro was found to lower the expression of G1phase inhibitor P27 at all concentrations tested (Table 8). The expression levels of cell cycle genes in MDA-MB-468 following Andro treatment did not indicate inhibition of the cell cycle. Interestingly, in MDAMB-231, CDK6 was lowered with concentrations of 5 and $20 \mu \mathrm{g} /$ $\mathrm{ml}$. Although the combination of Andro and BetA were not found 


\section{Cancer Therapy \& Oncology International Journal}

to alter the expression of the cell cycle genes tested in MDAMB-468 cell line, the combination lowered the expression of P21 and P27 in the MDA-MB-231 cell line. The exact mechanism by

Table 8: The effect of Andro on the mRNA expression levels of cell cycle genes in breast cancer cell lines MDA-MB-231 and MDA-MB-468 and their co-culturewith breast stromal cells*.

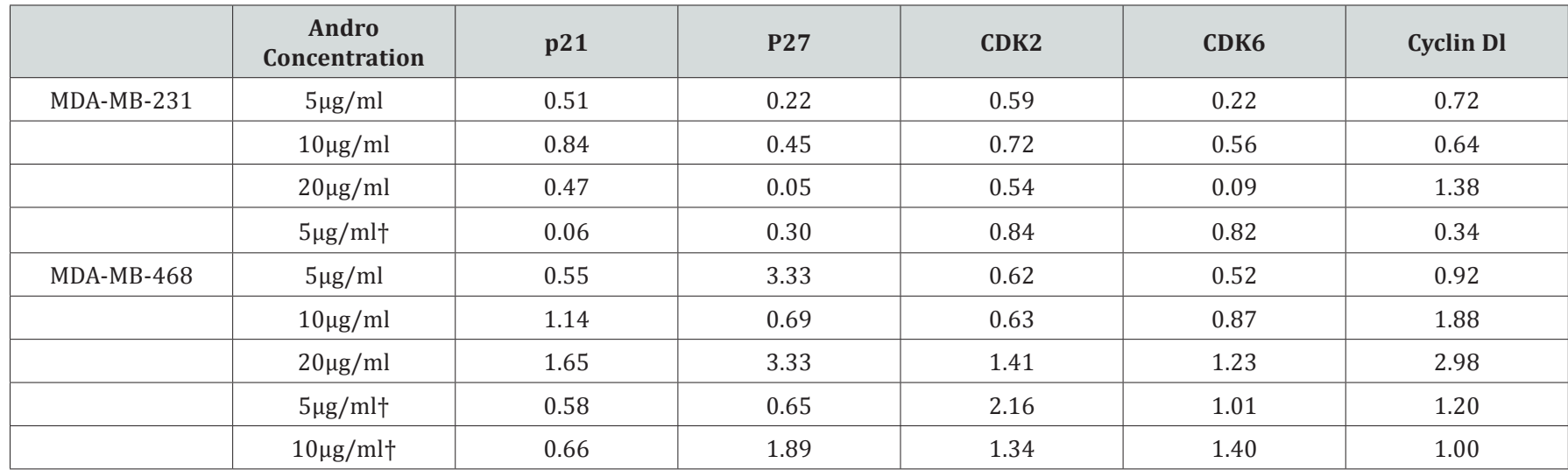

*The values represent fold change in expression of the target gene relative to the internal control gene ( $\beta$-actin) and untreated control cells. $\dagger$ Breast carcinoma cell line co cultured with breast stromal cells.

Table 9: The effect of combining Andro and BetA on the mRNA expression levels of cell cycle genes in breast cancer cell lines MDA-MB-231 and MDA-MB-468 co-culturedwith stromal cells*.

\begin{tabular}{|c|c|c|c|c|c|c|}
\hline & $\begin{array}{c}\text { Andro + BetA } \\
\text { Concentration }\end{array}$ & $\mathbf{p 2 1}$ & $\mathbf{P 2 7}$ & CDK2 & CDK6 & Cyclin Dl \\
\hline MDA-MB-231 & $5+5 \mu \mathrm{g} / \mathrm{ml}$ & 0.09 & 0.44 & 0.75 & 1.06 & 0.56 \\
\hline MDA-MB-468 & $5+5 \mu \mathrm{g} / \mathrm{ml}$ & 0.87 & 1.45 & 1.64 & 1.74 & 2.91 \\
\hline & $10+5 \mu \mathrm{g} / \mathrm{ml}$ & 0.52 & 2.39 & 1.26 & 1.18 & 0.72 \\
\hline
\end{tabular}

*The values represent fold change in expression of the target gene relative to the internal control gene ( $\beta$-actin) and untreated control cells.

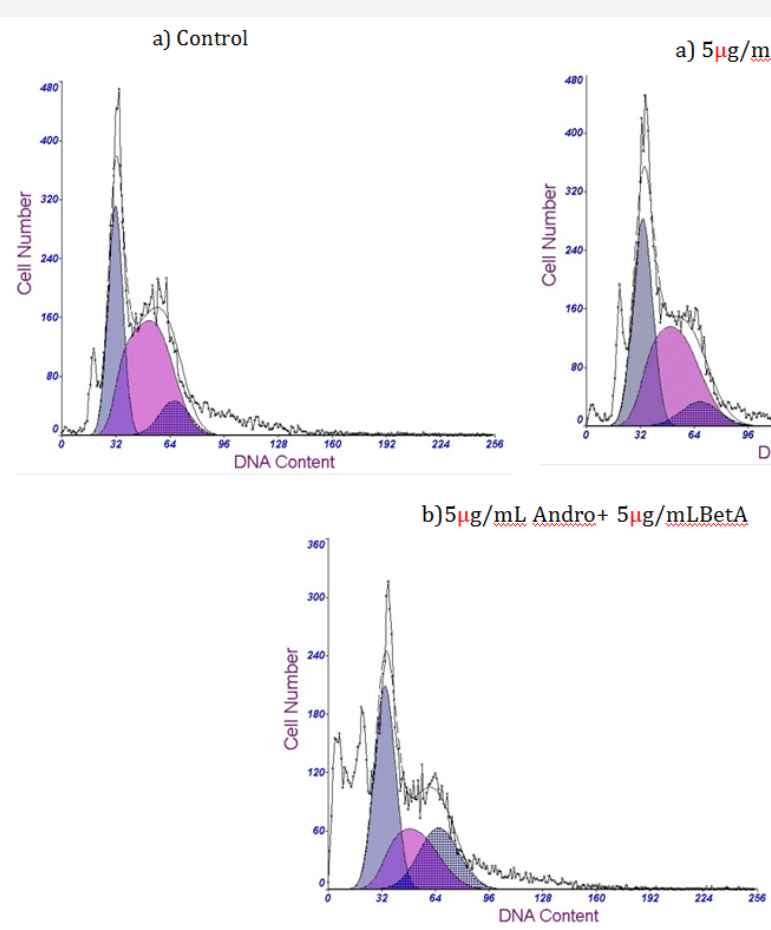

Figure 4: The effect of Andro on cell-cycle progression in MDA-MB-231 breast carcinoma cell lines co-cultured with breast stromal cells analysed using flow cytometry. Figure a) cell cycle of untreated cells, b) cell cycle is altered after the treatment of MDA-MB-231 with $5 \mu \mathrm{g} / \mathrm{mL}$ Andro, and c) cell cycle of MDA-MB-231 is significantly altered following treatment with the combination of $5 \mu \mathrm{g} / \mathrm{mLAndro}$ and $5 \mu \mathrm{g} / \mathrm{mLBetA}$. 


\section{Cancer Therapy \& Oncology International Journal}

The effect of Androand its combination with BetAon angiogenesis and the mRNA expression levels of VEGF and $\mathbf{b F G F}$

HMMEC alone and its co-culture with the TNBC cells or breast stromal cells underwent rapid reorganization and formed tube-like structures when plated on Matrigel. The treatment of HMMEC alone with $1 \mu \mathrm{g} / \mathrm{mL}$ Andro had no significant inhibitory effect on the Matrigel-induced network formations over the course of treatment. When HMMEC co-cultured with the breast carcinoma cell lines were treated with $1 \mu \mathrm{g} / \mathrm{mL}$ Andro, inhibition of networks were observed after $36 \mathrm{~h}$ of incubation (only images of HMMEC co-cultured with MBA-MD-231 cells are shown in Figure 4). The treatment of HMMEC co-cultured with breast stromal cells using $1 \mu \mathrm{g} / \mathrm{mL}$ Andro and the combination of $1 \mu \mathrm{g} /$ $\mathrm{mL}$ Andro with $1 \mu \mathrm{g} / \mathrm{mL}$ BetA caused significant inhibition of networks formed following 6,12, 24 and 36h incubation.

To further determine the mechanism behind the antiangiogenic activity of Andro and its combination with BetA in HMMEC, the mRNA expression levels of VEGF and bFGF were determined using RT-PCR. The mRNA expression levels of VEGF and bFGF following $1 \mu \mathrm{g} / \mathrm{mL}$ Andro treatment were lowered to $13.03 \%$ and $26.31 \%$ respectively, relative to the control. On the other hand, the combination of $1 \mu \mathrm{g} / \mathrm{mL}$ Androwith $1 \mu \mathrm{g} /$ $\mathrm{mL}$ BetA lowered the mRNA expression level of only bFGF to $11.84 \%$ (mRNA expression of VEGF remained unchanged). This is in line with our previous finding of BetA downregulating bFGF but not VEGF [15]. These findings further confirm that relatively low concentrations of Andro and its combination with BetA can modify HMMEC suggesting that the treatments may indeed prevent the process of angiogenesis.

\section{Discussion}

Herbal medicine is one of the most commonly used complementary therapies by people with cancer. Some studies have shown that as many as 6 out of every 10 people with cancer (60\%) use herbal remedies alongside conventional cancer treatments [17]. Chinese practitioners proposed that cancer therapy involves the interplay between the induction of cellcycle arrest, inhibition of angiogenesis, overcoming multidrug resistance (MDR), and boosting the immune system [18]. In this study, the efficacy of Andro and its combination with BetAin the treatment of triple negative breast carcinoma cell lines MDA-MB-231 and MDA-MB-468 was investigated. The rationale behind this idea is that plant products have been used for the treatment of human diseases including cancer for thousands of years due to their wide range of biological properties.

Androis known toexhibits potent anti-inflammatory and anti-canceractivities [19-21]. It has been found to exert growth inhibitory effects on colorectal, hepatoma, leukaemia and prostate cancer cells [20-24]. The results of this study show that Andro is also active against HMMEC and TNBC MDA-MB-231 and MDA-MB-468 cell lines, with increasing concentrations found to induce cell kill in all cell lines in a concentration dependent manner.

Furthermore, Andro has been reported to suppress inflammation and modulate the immune response by interfering with inflammatory mediators such as NF- $\kappa$ B, TNF- $\alpha$, IL-6, MIP-2, iNOS and COX-2[25]. Li et al. reported that Andro was effective in blocking inflammation by down regulating production of NO, TNF- $\alpha$ and IL-6 in macrophages[26]. In addition, Andro was found to inhibit TNF- $\alpha$ in in vitro and in vivo models of asthma [27]. Treatment of Andro to mice bearing castration-resistant DU145 human prostate tumors that express constitutive IL-6 autocrine loop significantly suppressed tumor growth [20]. Indeed, Androwas found to suppress the inflammation of MDA-MB-231 and MDA-MB-468 cell lines. It appears that the highest concentration of Andro $(20 \mu \mathrm{g} / \mathrm{mL})$ was the most effective at lowering the expression of the inflammatory factors in MDA-MB-231 cell line. At that concentration, Androblocked inflammation through down regulatingthe expression of IL-6, HIF1A, STAT3, i-NOS and TLR4. Furthermore, Andro was found to lower the expression ofTNF- $\alpha, N F-\kappa B$ and HIF1A in MDAMB-468 cell line when low ( 5 and $10 \mu \mathrm{g} / \mathrm{mL}$ ). When Andro was combined with BetA, the expression of TNF-a, TLR4, NF-kB1 and IL- 6 were altered. The results indicate the ability of Andro to inhibit the expression of inflammatory genes.

Besides blocking the inflammatory response in these cell lines, the mechanism of Andro-induced cell cycle arrest was investigated. Andro inhibits cell-cycle progression by modulating the expression of cell cycle related proteins. The induction of cell-cycle arrest occurs at G1 phase and is mainly due to the induction of cell-cycle inhibitory proteins p16, p21, p27 associated with decreased expression of cyclin A, cyclin D, CDK4 and CDK2, required for G1 to $S$ transition $[10,22,28]$. Andro was found to lower the percentage of S-phase cells, increase the percentage of G1 phase cells thus causing G1 phase cell cycle arrest in MDA-MB-231 cell line co-cultured with breast stromal cells.On the other hand, flow cytometric analysis did not show arrest of the cell cycle in MDA-MB-468 cell line at the concentrations tested, in fact the percentage of cells in the $S$ phase increased. This may be partly due to the use of concentrations that are lower than the IC50 of Andro against this cell line, thus higher concentrations may be necessary to provide a better understanding of the mechanism of Andro-induced cell cycle arrest in MDA-MB-468 cell line. Although the mRNA expression levels of cell cycle genes in Andro treated MDA-MB-231 and MDA-MB-468 cell lines were determined, the results were inconclusive. In addition to the induction of cell cycle arrest, Andro causes apoptosis through altering the interplay between pro- and anti-apoptotic proteins. Cheung et al. reported that androemployed an intrinsic mitochondria-dependent pathway of apoptosis by regulating the expression of some pro-apoptotic markers in HL-60. Apoptosis was associated with disappearance of mitochondrial cytochrome $\mathrm{c}$ and increased expression of Bax, 


\section{Cancer Therapy \& Oncology International Journal}

but decreased expression of Bcl-2 proteins [24]. Another study showed that Andro induced activation of mitogen-activated protein kinases (MAPKs) including p38 kinase, c-Jun N-terminal kinase (JNK) and extracellular signal-related kinases (ERK1/2), but had no significant effect on caspase-3, Bcl-xL and Bcl-2, which are apoptosis-related proteins. Moreover, inhibition of JNK activation partially rescued the toxic effect of Andro on Hep3B cells [23].

The anti-tumour activity of Andro is multifactorial, with possible anti-angiogenicproperties [29,30]. While in this study Androhad no significant anti-angiogenic effect on HMMEC cultured alone, it inhibited angiogenesis in HMMEC co-cultured with breast carcinoma cell lines MDA-MB-231 and MDA-MB-468 and caused significant inhibition in HMMEC co-cultured with breast stromal cells. Two factors associated with angiogenesis are basic fibroblast growth factor (bFGF) and vascular endothelial growth factor (VEGF) [31,32]. Interestingly, the mRNA expression levels of VGEF and bFGF in this study indicated that Andro inhibited angiogenesis through the inhibition of both bFGF and VEGF. The expression levels of bFGF and VEGF were lowered to $26.31 \%$ and $13.03 \%$ in comparison to the control respectively. It was previously found that BetA inhibited angiogenesis through the down regulation of $\mathrm{bFGF}$ rather than VEGF (article in print). The results indicate that the antiangiogenic activity of Andro may be mediated via the inhibition of VEGF and bFGF, whereas BetA is an inhibitor of angiogenesis by lowering the expression of bFGF when in combination with Andro. Finally, the selective cytotoxicity of Andro against tumour cells and its chemo-protective potential towards normal cells makes it an ideal candidate for combination therapies [33].

In summary, Andro proved to be a potentanti-proliferative, anti-inflammatory, and anti-angiogenic agent against MDAMB-231 and MDA-MB-468 breast carcinoma cell lines. Given the fact that Andro and its combination with BetA are shown to be effective in vitro against TNBC, further studies are clearly warranted to determine its in vivo effect. The effectiveness of Andro and its combination with BetA indicate that they may be highly effective and have great potential in inhibiting cancer proliferation, inflammation and angiogenesis.

\section{Conflict Of Interest}

The Authors declare that they have no financial interest and personal relationships with other people or organizations that could inappropriately influence (bias) their work.

\section{Reference}

1. Jemal A, Siegel R, Xu J, Ward E (2010) Cancer Statistics. CA Cancer J Clin 60(5): 277-300

2. Karhade M (2012) Survival analysis of circulating tumor cells in triplenegative breast cancer [M.P.H.]. Texas, The University of Texas School of Public Health, USA.

3. Carey LA, Dees EC, Sawyer L, Graham ML, Perou CM, et al. (2007) The Triple Negative Paradox: Primary Tumor Chemosensitivity of Breast Cancer Subtypes. Clin Cancer Res 13(8): 2329-2334.
4. Ueno NT, Zhang D (2011) Targeting EGFR in Triple Negative Breast Cancer. Journal of Cancer 2: 324-328.

5. Oakman C, Viale G, Di Leo A (2010) Management of triple negative breast cancer. The Breast 19(5): 312-321.

6. Weber D, Wheat JM, Currie GM (2010) Inflammation and cancer: tumor initiation, progression and metastasis, and Chinese botanical medicines. Journal of Chinese Integrative Medicine 8(11): 1006-1013.

7. Pierce BL, Ballard-Barbash R, Bernstein L, Sorensen BE, McTiernan A, et al. (2009) Elevated Biomarkers of Inflammation Are Associated With Reduced Survival Among Breast Cancer Patients. J Clin Oncol 27(21): 3437-3444.

8. Aggarwal BB, Vijayalekshmi RV, Sung B (2009) Targeting Inflammatory Pathways for Prevention and Therapy of Cancer: Short-Term Friend Long-Term Foe. Clin Cancer Res 15(2): 425-430.

9. Sukardiman H, Widyawaruyanti A, Sismindari, Zaini NC (2007) Apoptosis inducing effect of andrographolide on TD-47 human breast cancer cell line. Afr J Tradi Complementary Altern Med 4(3): 345-351.

10. Rajagopal S, Kumar RA, Deevi DS, Satyanarayana C, Rajagopalan R (2003) Andrographolide, a potential cancer therapeutic agent isolated from Andrographis paniculata. J Exp Ther Oncol 3(3): 147-158.

11. Shen YC, Chen CF, Chiou WF (2002) Andrographolide prevents oxygen radical production by human neutrophils: possible mechanism(s) involved in its anti-inflammatory effect. Br J Pharmacol 135(2): 399406.

12. Pisha E, Chai H, Lee IS, Kinghorn AD, Brown DM, et al. (1995) Discovery of betulinic acid as a selective inhibitor of human melanoma that functions by induction of apoptosis. Nat Med 1(10): 1046-1051.

13. Moghaddam M G, Ahmad F B H, A SK (2012) Biological Activity of Betulinic Acid: A Review. Pharmacology \& Pharmacy 3(2): 119-123.

14. Cailleau R, Olivé M, Cruciger QJ (1978) Long-term human breast carcinoma cell lines of metastatic origin: Preliminary characterization. In Vitro 14(11): 911-915.

15. Daniel Weber, Mixia Zhang, Pengwei Zhuang, Janelle Wheat, Geoffrey Currie, et al. (2014) The efficacy of betulinic acid in triple-negative breast cancer. SAGE Open Medicine 2.

16. Livak KJ, Schmittgen TD (2001) Analysis of Relative Gene Expression Data Using Real-Time Quantitative PCR and the 2- $\Delta \Delta \mathrm{CT}$ Method. Methods 25(4): 402-408.

17. UK CR (2015) Herbal medicine. 2015; http://www.cancerresearchuk. org/about-cancer/cancers-in-general/treatment/complementaryalternative/therapies/herbal-medicine - evidence. Accessed 17/2/15.

18. Parekh H, Liu G, Wei M (2009) A new dawn for the use of traditional Chinese medicine in cancer therapy. Mol Cancer 8(1): 21.

19. Bao Z, Guan S, Cheng C, Leung BP, Wong WS, et al. (2009) A Novel Antiinflammatory Role for Andrographolide in Asthma via Inhibition of the Nuclear Factor-кB Pathway. Am J Respir Crit Care Med 179(8): 657-665.

20. Chun JY, Tummala R, Nadiminty N, Joy Yang, Christopher P, et al. (2010) Andrographolide, an Herbal Medicine, Inhibits Interleukin-6 Expression and Suppresses Prostate Cancer Cell Growth. Genes Cancer1(8): 868-876.

21. Manikam ST, Stanslas J (2009) Andrographolide inhibits growth of acute promyelocytic leukaemia cells by inducing retinoic acid receptorindependent cell differentiation and apoptosis. J Pharm Pharmacol 61(1): 69-78.

22. Shi MD, Lin HH, Lee YC, Chao JK, Lin RA, et al. (2008) Inhibition of cell-cycle progression in human colorectal carcinoma Lovo cells by andrographolide. Chem. Biol Interact 174(3): 201-210. 


\section{Cancer Therapy \& Oncology International Journal}

23. Ji L, Liu T, Liu J, Chen Y, Wang Z (2007) Andrographolide Inhibits Human Hepatoma-Derived Hep3B Cell Growth through the Activation of c-Jun N-Terminal Kinase. Planta Med 73(13): 1397-1401.

24. Cheung HY, Cheung SH, Li J, Fong WF, Leung FM, et al (2005) Andrographolide Isolated from Andrographis paniculata Induces Cell Cycle Arrest and Mitochondrial-Mediated Apoptosis in Human Leukemic HL-60 Cells. Planta Med 71(12): 1106-1111.

25. Chao WW, Kuo YH, Lin BF (2010) Anti-inflammatory Activity of New Compounds from Andrographis paniculata by NF- $\mathrm{kB}$ Transactivation Inhibition. J Agric Food Chem 58(4): 2505-2512.

26. LI Ming, CHEN Wei-qiang, HU Tai-ping, ZHANG Li-rong, CAI Youbiao, Hong-biao G (2010) Andrographolide inhibits LPS-induced inflammation factors expression in macrophage cells. Journal of Guangdong Pharmaceutical College 4.

27. Abu-Ghefreh AaA, Canatan H, Ezeamuzie CI (2009) In vitro and in vivo anti-inflammatory effects of andrographolide. Int Immunopharmaco 9(3): 313-318.

28. Satyanarayana C, Deevi D, Rajagopalan R, Srinivas N, Rajagopal S
(2004) DRF 3188 a novel semi-synthetic analog of andrographolide: cellular response to MCF 7 breast cancer cells. BMC Cancer 4(1): 26 .

29. Sheeja K, Guruvayoorappan C, Kuttan G (2007) Antiangiogenic activity of Andrographis paniculata extract and andrographolide. Int Immunopharmacol 7(2): 211-221.

30.Zhao F, He EQ, Wang L, Liu K (2008) Anti-tumor activities of andrographolide, a diterpene from Andrographis paniculata, by inducing apoptosis and inhibiting VEGF level. J Asian Nat Prod Res 10(5): 467-473.

31. Ferrara N (2004) Vascular Endothelial Growth Factor: Basic Science and Clinical Progress. Endocr Rev 25(4): 581-611.

32. Presta M, Dell'Era P, Mitola S, Moroni E, Ronca R, et al. (2005) Fibroblast growth factor/fibroblast growth factor receptor system in angiogenesis. Cytokine Growth Factor Rev 16(2):159-178.

33. Varma A, Padh H, Shrivastava N (2011) Andrographolide: A New PlantDerived Antineoplastic Entity on Horizon. Evid Based Complement Alternat Med 2011.

\section{Your next submission with Juniper Publishers will reach you the below assets}

- Quality Editorial service

- Swift Peer Review

- Reprints availability

- E-prints Service

- Manuscript Podcast for convenient understanding

- Global attainment for your research

- Manuscript accessibility in different formats

( Pdf, E-pub, Full Text, Audio)

- Unceasing customer service

Track the below URL for one-step submission https://juniperpublishers.com/online-submission.php 